Thabiea : Journal of Natural Science Teaching
Program Studi Tadris Ilmu Pengetahuan Alam
Institut Agama Islam Negeri Kudus
http://journal.stainkudus.ac.id/index.php/Thabiea
p-issn: 25808474

\title{
DESKRIPSI SAINTIFIK PENGARUH TANAH PADA PERTUMBUHAN TANAMAN: Studi Terhadap QS. Al A'raf Ayat 58
}

\author{
Anggun Zuhaida ${ }^{a, 1}$, Wawan Kurniawan ${ }^{\mathrm{b}, 2}$ \\ a,b Tadris IPA, FTIK IAIN Salatiga \\ 1 anggunzuh@iainsalatiga.ac.id; ${ }^{2}$ wawanwtg7@gmail.com
}

\begin{tabular}{ll}
\hline Kata kunci: & ABSTRAK \\
\hline Pertumbuhan & Penelitian ini bertujuan untuk mendeskripsikan maksud dari QS. Al A'raf \\
Tanaman & ayat 58 dimana terdapat isyarat ilmiah yang menarik untuk dikaji. Allah \\
Tanah & telah menciptakan tumbuhan yang mana dapat tumbuh dari tanah yang \\
Saintifik & baik. Isyarat Ilmiah yang disebutkan masih bersifat global sehingga perlu \\
& kajian yang lebih spesifik untuk mengetahui secara detail makna dari ayat \\
& tersebut. Metode yang digunakan adalah metode penelitian pustaka yakni \\
& mengumpulkan data atau bahan dari berbagai sumber ilmu yang \\
& diperlukan dalam menyelesaikan artikel ini. Hasil kajian menunjukan \\
& bahwa dalam QS. Al A'raf ayat 58 tentang tanah yang baik adalah tanah \\
& yang subur. Tanaman dapat tumbuh yang salah satu syaratnya yaitu adanya \\
& tanah atau media tanam. Media yang baik (subur) akan membuat tanaman \\
& tersebut tumbuh dengan baik. Kandungan mineral yang cukup dalam tanah \\
& merupakan pengaruh utama terhadap tanaman untuk tumbuh. Tanah yang \\
& subur dipengaruhi oleh berbagai faktor seperti mineral, kadar pH, \\
& kelembapan, lapisan humus dan kadar biota. Tanaman akan tumbuh subur \\
& pada tanah yang baik sehingga tanah yang subur tentu menjadi ladang \\
& rezeki bagi manusia. Deskripsi saintifik pada Al-Qur'an akan memberikan \\
& pengetahuan dari dua sisi ilmu yang berbeda (sains dan agama). Karena \\
pada dasarnya ilmu yang ada di dalam Al-Qur'an sudah tidak diragukan & lagi. Dengan begitu, manusia diwajibkan untuk menjaga kelestarian atau \\
kesuburan tanah sebagai wujud syukur dan iman kepada Allah Swt atas & apa yang telah karuniakan kepada manusia.
\end{tabular}

\begin{tabular}{l}
\hline Key word: \\
\hline Growth \\
Plants \\
Soil \\
Scientific
\end{tabular}

\section{ABSTRACT}

This study aims to describe the purpose of QS. Al A'raf : 58 where there are interesting scientific cues to study. God has created plants which can grow from good soil. Scientific Cues mentioned are still global in nature, so a more specific study is needed to find out in detail the meaning of the verse. The method used is a library research method that is collecting data or material from various sources of knowledge needed in completing this article. The results of the study show that in QS. Al A'raf : 58 concerning good land is fertile land. Plants can grow, one of the conditions is the presence of soil or planting media. Good media (fertile) will make the plant grow well. Sufficient mineral content in the soil is the main influence on plants to grow. Fertile soil is influenced by various factors such as minerals, $\mathrm{pH}$ levels, humidity, humus layer and biota levels. Plants will thrive on good soil so that fertile land is certainly a field of sustenance for humans. The scientific description of the Qur'an will provide knowledge from two different sides of science (science and religion). Because basically the knowledge that is in the Qur'an is no doubt. That way, humans are required to maintain the preservation or fertility of the land as a form of gratitude and faith in Allah SWT for what has been granted to humans.

Copyright $\odot 2018$ Institut Agama Islam Negeri Kudus. All Right Reserved 


\section{Pendahuluan}

Sains adalah produk manusia karenanya membawa pandangan dunia manusia di belakangnya. Sains dapat dikatakan sebagai produk manusia dalam menyibak realitas. Setiap bangunan ilmu pengetahuan atau sains selalu berpijak pada tiga pilar utama, yakni pilar ontologis, aksiologis, dan epistemologis. Tiga pilar sains islam harus dibangun dari prinsip tauhid yang tersari dalam kalimat laa ilaaha illallah dan terdiskripsi dalam rukun iman dan rukun islam. Pilar ontologis, yakni hal yang menjadi subjek ilmu, islam harus menerima realitas material maupun nonmaterial. Pilar kedua bangunan ilmu pengetahuan adalah pilar aksiologis, terkait dengan tujuan ilmu pengetahuan dibangun atau dirumuskan. Pilar ketiga dan terpenting adalah pilar epistemologis yaitu bagaimana atau dengan apa kita mencapai pengetahuan (Purwanto, 2008).

Al-Quran secara terminologis adalah Kalam Allah swt yang merupakan mukjizat yang diturunkan (diwahyukan) kepada Nabi Muhammad saw yang ditulis di mushaf dan diriwayatkan secara muttawatir dan membacanya adalah ibadah (Choiri : 2014). Dalam Al-Qur'an terdapat banyak ilmu yang berkaitan dengan sains maupun ilmu sosial. Sains dalam Al-Qur'an merupakan hal yang sudah pasti akan tetapi manusia tentu memiliki keterbatasan untuk mengetahui secara detail maksud dari suatu ayat tersebut.

Seiring perkembangan zaman, teknologi dan ilmu pengetahuan semakin berkembang. Sudah banyak ilmu sains dalam Al-Qur'an yang telah terbukti kebenarannya. Salah satu ayat dalam Al-Qur'an yang menarik untuk dikaji adalah QS. Al-A'raf ayat 58. Dalam ayat tersebut terdapat isyarat ilmiah tentang hubungan antara tanah dan tumbuhan yang menarik untuk dikaji. Seorang saintis muslim tentu mengetahui bahwa Al-Qur'an merupakan sumber ilmu.

Suatu teori pada sains harus didukung dengan bukti (evidence) yang kuat. Antara teori yang satu dengan yang lainnya harus kompatibel, tidak boleh ada pertentangan. Begitu juga ketika mengajukan hipotesis baru. Suatu kejadian bisa diprediksi dengan mendeduksi dari teori yang sudah diketahui. Korelasi antara dua kejadian atau lebih bisa terlihat dari data statistik dan sebagainya. Proses mempelajari sains dengan benar akan melatih kita menggunakan prinsip-prinsip logika dalam mengevaluasi apakah informasi yang kita peroleh itu benar atau salah. Proses pelatihan ini akan mengasah ketajaman kita dalam berpikir kritis dan menggunakan logika (Subekti, 2012).

Pendidikan Sains berasal dari 2 kata yaitu pendidikan dan sains. Pendidikan berhubungan dengan perkembangan ilmu pendidikan yang mencakup strategi, metode, media, kurikulum, evaluasi dan lain-lain yang kepentingannya untuk memajukan pendidikan di Indonesia khususnya. Sedangkan sains berhubungan dengan 3 wilayah ilmu alam/IPA yaitu ilmu fisika, kimia, dan biologi. Pendidikan sains dapat dikategorikan ilmu yang didapat, diolah untuk alam dan dimanfaatkan untuk kehidupan manusia bermasyarakat. Untuk itu materi yang di cakup tidak lepas dari alam (Horiq, 2014). Dalam integrasi Al Qur'an dapat dikategorikan sebagai bagian dari pendidikan sains khususnya bagi umat islam. Kandungan dalam Al-Qur'an dapat dikatikan dengan permasalahan (ilmu) sains yang ada.

Manusia merupakan khalifah dibumi yang diharuskan untuk menjaga bumi ini sebaikbaiknya. Menjadi khalifah yang baik adalah bukti bahwa kita iman kepada Allah Swt. Ada berbagai macam cara untuk menjadi khalifah yang baik karena setiap manusia memiliki kemampuan di bidangnya masing-masing. Sebagai pendidik, dapat kita lakukan dengan menularkan ide-ide kebaikan dan bermanfaat bagi sesama manusia tanpa menimbulkan efek negatif. Sebagai scientist muslim, tentu kita bisa belajar lebih akan ilmu yang ada di Al-Qur'an dengan ilmu sains secara umum.

Oleh karena itu, dengan mengkaji QS. Al A'raf ayat 58, kita akan mengetahui bahwa teori Al-Qur' an benar adanya dengan bukti-bukti ilmiah yang telah ada di lapangan. Dengan begitu penulis dan pembaca diharapkan menjadi manusia yang tentunya semakin bertambah keimanannya dan selalu bersyukur atas apa yang telah Allah berikan kepada manusia (Tumbuhan) salah satunya dengan memelihara lingkungan (tanah) tempat tumbuhan dan manusia hidup..

\section{Metode}

Penelitian ini merupakan penelitian pustaka (library research) (Sukardi, dalam Batubara, 2016), dikarenakan data-data atau bahan-bahan yang diperlukan dalam menyelesaikan penelitian tersebut berasal dari perpustakaan baik berupa buku, ensklopedi, 
kamus, jurnal, dokumen, majalah dan lain sebagainya. Secara garis besar, sumber bacaan yang ada di perpustakaan dapat dibedakan menjadi dua kelompok yaitu:

a. Sumber acuan umum yang biasanya berisi tentang teori-teori dan konsep-konsep pada umumnya yaitu kepustakaan yang berwujud buku-buku teks, ensklopedi, monograp, dan sejenisnya.

b. Sumber acuan khusus yaitu berupa junal, bulletin penelitian, tesis dan lain-lain (Joseph Komider, dalam Harahap, 2014)

Penelitian ini berkaitan dengan pemahaman tentang metode dan model integrasi sains dan Islam di Perguruan Tinggi, secara metodologis penelitian ini dapat dimasukkan dalam kategori penelitian eksploratif (Arikunto dalam Batubara, 2016). Jadi, penelitian ini adalah kajian ilmiah yang memadukan ilmu sains dan Islam dengan menganalisis berbagai sumber referensi..

\section{Hasil dan pembahasan}

\section{a. Al-Qur'an Surah Al A'raf Ayat 58 dan Tafsirnya}

Al Qur'an Surah Al A'raf yang secara harfiah bermakna tempat-tempat yang tinggi dengan aneka makna yang dapat dikandungnya. Jumlah ayatnya terdiri dari 206 ayat, keseluruhannya turun di Mekkah sebelum Nabi saw. berhijrah ke Madinah. Secara singkat, dapat dikatakan bahwa tujuan utama dari surah ini adalah peringatan serta ancaman siksa duniawi dan ukhrawi terhadap yang berpaling dari ajakan para Nabi, yakni kepercayaan tauhid, keniscayaan, hari kiamat, kebajikan, dan kesetiaan (Sihab, 2013:11).

$$
\begin{aligned}
& \text { QS. Al-A'raf ayat } 58
\end{aligned}
$$

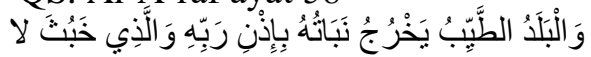

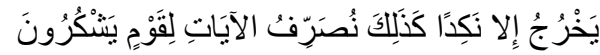

Yang Artinya, "Dan tanah yang baik, tanaman-tanamannya tumbuh subur dengan izin Tuhan dengan pemeliharanya; dan (tanah) yang buruk, tanaman-tanamannya tumbuh merana. Demikianlah Kami menjelaskan berulang-ulang tanda-tanda (kebesaran Kami) bagi orang-orang yang bersyukur." (Sihab, 2013:158).

Dengan mengetahui artinya saja, kita tentu sudah tau bahwa ayat ini berhubungan erat dengan kesuburan tanah. Seperti tafsir dari Departemen Agama RI menjelaskan jenis-jenis tanah di muka bumi ini ada yang baik dan subur, bila dicurahi hujan sedikit saja, dapat menumbuhkan berbagai macam tanaman dan menghasilkan makanan yang berlimpah ruah dan ada pula yang tidak baik, meskipun telah dicurahi hujan yang lebat, namun tumbuhtumbuhannya tetap hidup merana dan tidak dapat menghasilkan apa-apa (Departemen Agama RI, 2009). Kandungan tafsir tersebut berhubungan dengan ilmu biologi yang fokus ke tanaman. Dimana kita tahu bahwa tanaman secara umum membutuhkan media tanam berupa tanah yang subur. Tanah yang subur akan membuat tanaman tumbuh secara bertahap.

Sementara itu, dari sisi agama memiliki tafsir bahwa Allah memberikan perumpamaan dengan hidupnya kembali tanah-tanah yang mati, untuk menetapkan kebenaran terjadinya Yaumul Mahsyar. Yaitu dimana orang-orang mati dihidupkan kembali dikumpulkan di Padang Mahsyar untuk menerima ganjaran bagi segala pebuatannya, yang baik dibalas berlipat ganda dan yang buruk dibalas dengan yang setimpal. Allah memberikan perumpamaan pula dengan tanah yang baik dan subur serta tanah yang buruk dan tidak subur untuk menjelaskan sifat dan tabiat manusia dalam menerima dan menempatkan petunjuk Allah (Departemen Agama RI, 2009).

Sebagai ilmuan muslim kita membutuhkan tafsir dan juga pengetahuan berbagai bidang ilmu seperti biologi (tanah dan tanaman). Hal ini karena kandungan QS. AlA'raf diatas tentu masih bersifat global. Untuk itu akan membahas lebih lanjut secara detail hubungan antara tanah yang subur dengan pertumbuhan tanaman.

\section{b. Tanah dan Pengaruhnya}

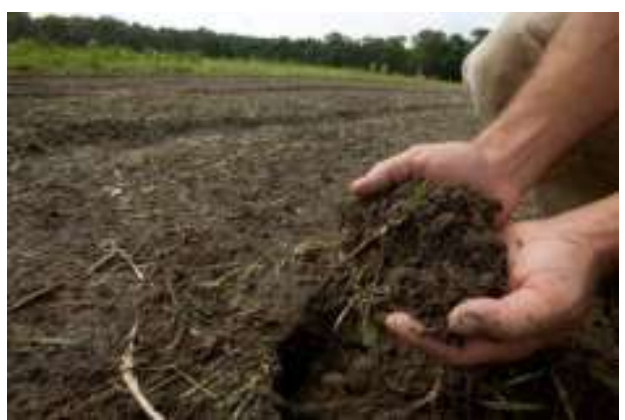

Gambar 1: Tanah yang Subur

(Sumber: https://kabartani.com/langkah-dalammengembalikan-kesuburan-tanah.html)

Dalam kamus biologi, tanah adalah lapisan kerak bumi yang terlapuk dan terlekang dan mungkin tercampur bahan organik (Rifai, 
2003:462). Tanah adalah bahan mineral yang tidak padat (unconsolidated) terletak di permukaan bumi, yang telah dan akan tetap mengalami perlakuan dan dipengaruhi oleh faktor-faktor genetik dan lingkungan yang meliputi bahan induk, iklim (termasuk kelembapan dan suhu), organisme (makro dan mikro) dan topografi pada suatu periode dan waktu tertentu.

Tanah mineral yang berfungsi sebagai media tumbuh ideal secara material tersusun oleh 4 komponen, yaitu bahan padatan (mineral dan organik), air dan udara. Berdasarkan volumenya, maka tanah secara reratal terdiri dari: (1) 50\% padatan, berupa 45\% mineral, dan $5 \%$ bahan organik, dan (2) 50\% ruang pori, berisi $25 \%$ air dan $25 \%$ udara.

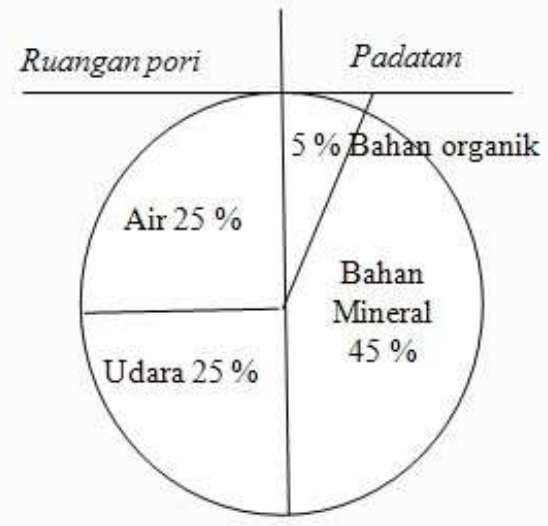

Gambar 2: Diagram komponen tanah yang ideal

Masing-masing komponen tanah tersebut berperan penting dalam menunjang fungsi tanah sebagai media tumbuh. Udara $\left(\mathrm{O}_{2}\right.$, $\mathrm{CO}_{2}, \mathrm{~N}_{2}$, dll) berfungsi sebagai gudang dan sumber gas. Adanya sirkulasi udara (aerasi) yang baik akan memungkinkan pertukaran gas-gas ini dengan $\mathrm{O}_{2}$ dari atmosfer, sehingga aktivitas mikrobia autotrofik yang berperan vital dalam penyediaan unsur-unsur hara menjadi terjamin dan toksisitas gas-gas tersebut ternetralisir.

Air tanah berfungsi sebagai komponen utama tubuh tetanaman dan biota tanah. Sebagian besar ketersediaan dan penyerapan hara oleh tanaman dimediasi oleh air, malah unsur-unsur mobil seperti N, K dan Ca dominan diserap tanaman melalui bantuan mekanisme massa air, baik ke permukaan akar maupun transportasi ke daun. Oleh karena itu, tanaman yang mengalami defisiensi (kekurangan) air tidak saja akan layu tetapi juga akan mengalami defisiensi hara.

Secara langsung bahan organik tanah merupakan sumber senyawa-senyawa organik yang dapat diserap tanaman meskipun dalam jumlah sedikit, seperti alanin, glisin, dan asamasam amino lainnya, juga hormon /zat perangsang tumbuh dan vitamin. sebagai

Secara fisik, bahan organik berperan

1. Memengaruhi warna tanah menjadi coklathitam

2. Merangsang granulasi, serta

3. Menurunkan plastisitas dan kohesi tanah

4. Memperbaiki struktur tanah menjadi lebih remah, dan

5. Meningkatkan daya tanah menahan air sehingga drainase tidak berlebihan, kelembaban dan temperatur tanah menjadi stabil.

Secara kimiawi, bahan organik berperan sebagai:

1. Bagian mudah terurai melalui proses mineralisasi akan menyumbangkan sejumlah ion-ion hara

2. Menghasilkan humus tanah yang terutama berperan secara koloidal

3. Menghindarkan ion-ion hara dari pelindian oleh aliran massa air

4. Ketersediaan basa-basa meningkat

5. Menghasilkan peningkatan ketersediaan dan efisiensi pemupukan

Secara ekologis, tanah tersusun oleh 3

kelompok material, yaitu material hidup (faktor biotik) berupa biota (jasad-jasad hayati), faktor abiontik berupa bahan organik, dan fakto abiotik berupa pasir debu dan liat (Ali, 2005).

Kesuburan tanah adalah kondisi atau keadaan dan kemampuan tanah untuk mendukung pertumbuhan tanaman dengan berbagai komponen yang ada didalamnya seperti biologi, kimiawi dan fisika. Banyak yang menduga bahwa kesuburan tanah sama dengan kesehatan tanah, pada kenyataan-nya tidaklah selalu demikian, karena kesehatan tanah sudah berbeda lagi cakupan pembahasan-nya. Kesehatan tanah lebih diartikan sebagai suatu kondisi atau keadaan tanah yang mendukung dan menjamin tanaman dapat tumbuh dan berkembang secara optimal tanpa adanya gangguan dari berbagai aspek (Sari, 2015).

Ciri ciri tanah subur yang penjelasannya sebagai berikut:

1) Memiliki Lapisan Humus Tebal

Suatu tanah yang subur dapat diketahui dengan melihat ketebalan bunga tanah atau humus. Semakin tebal maka menandakan tanah tersebut kaya dengan bahan organik dan unsur 
hara sehingga tanaman dapat menyerap zat hara tersebut sebagai bahan baku untuk melakukan proses fotosintesis. Ketersediaan humus juga sebagai tanda bahwa sistem drainase lahan sekitar yang baik. Humus yang tebal akan meningkatkan daya hisap tanah terhadap air, hal ini disebabkan struktur lapisan humus berongga sehingga memungkinkan air untuk masuk lebih banyak.

\section{2) Memiliki PH Yang Netral}

Tanah yang baik haruslah memiliki tingkat keasaman yang seimbang, perlu diketahui $\mathrm{PH}$ normal tanah berada pada kisaran 6 hingga 8 atau pada kondisi terbaik memiliki PH 6.5 hingga 7.5. Tanah dengan tingkat $\mathrm{PH}$ yang netral memungkinkan untuk tersedianya berbagai unsur kimiawi tanah yang seimbang. Itulah kenapa pada kondisi tanah yang terlalu asam perlu dilakukan proses pengapuran yang tujuannya yaitu untuk mengembalikan $\mathrm{PH}$ tanah ke kondisi netral. Begitu juga ketika tanah bersifat terlalu basa ( $>\mathrm{PH}$ 8) perlu diberikan Sulfur atau belerang yang terkandung pada pupuk ZA (Amonium Sulfat). Dengan PH yang netral, tumbuhan akan lebih mudah menyerap ion-ion unsur hara dan menjaga perkembangan mikroorganisme tanah.

3) Memiliki Tekstur Lempung

Tanah yang subur akan berstruktur lempung yang berfungsi untuk mengikat berbagai mineral sehingga tidak mudah hanyut terbawa air. Namun kadar lempung haruslah normal dan biasanya terletak pada lapisan tanah tengah. Selain itu juga memiliki kandungan pasir yang mencukupi, manfaatnya supaya memungkinkan terjadinya drainase dan air dapat terserap kedalam tanah dengan baik.

4) Kaya Dengan Biota Tanah

Kehadiran sejumlah makhluk hidup berukuran kecil penghuni tanah sebagai tanda bahwa didalam tanah tersebut tersedia berbagai bahan organik yang juga dibutuhkan mikroorganisme untuk menunjang hidupnya. Jadi mikrofauna dan mikroflora berperan sebagai indikator kesuburan tanah (Sari, 2015).

Selain ciri-ciri diatas, salah satu tanda atau ciri suatu tanah dikatakan subur dengan memperhatikan vegetasi yang tumbuh diatasnya. Semakin banyak dan beragam jenis tanaman yang tumbuh maka semakin baik kualitas tanah tersebut. Sebagai contoh di pegunungan memiliki berbagai macam tanaman seperti bunga, rumput, buah, dan lain sebagainya. Unsur-unsur dalam tanah tersebut dapat dibilang cukup lengkap memenuhi nutrisi berbagai tumbuhan yang ada.

Tanah yang subur merupakan tanah yang memiliki banyak komponen sebagai syaratnya. Karena tanah yang subur tentu harus dapat ditanami oleh tanaman. Tanah yang tidak subur akan membuat tanaman terganggu pertumbuhannya. Kadar unsur yang ada dalam tanah berpengaruh terhadap pemenuhan kebutuhan nutrisi tanaman. Tanaman membutuhkan berbagai unsur hara yang ada dalam tanah untuk pertumbuhannya. Disamping itu, jenis tumbuhan yang tertanam memiliki kebutuhan unsur yang berbeda pula.

\section{c. Tanaman dan Pertumbuhannya}

Tanaman (crop plant) adalah tumbuhan-tumbuhan yang dibudidayakan oleh manusia, karena itu mereka ditanam dan dipelihara untuk diambil hasilnya (Rifai, 2003:462). Tanaman merupakan organisme autotrof yang dapat menghasilkan bahan organik untuk keperluan hidupnya dan menjadi ujung rantai makanan bagi beragam jenis organisme heterotof. (Odum dalam Nugroho: 2015) Tumbuhan merupakan organisme yang sepenuhnya menyesuaikan diri dengan kehidupan di darat, meskipun beberapa di antaranya hidup di air seperti teratai. Oleh karena itu, tumbuhan (Plantae) berupa kormus (memiliki akar, batang dan daun sejati), bahanbahan yang diperlukan tumbuhan, seperti cahaya, $\mathrm{CO}_{2}$, air, dan mineral diperoleh melalui berbagai proses yang terjadi pada ketiga organ tersebutSelain itu, semua tumbuhan memiliki kloroplas dengan klorofil a dan klorofil b. Sedangkan kanggang hijau diketahui hanya memiliki klorofil $b$.

Pertumbuhan adalah suatu proses pertambahan ukuran, baik volume, bobot, jumlah sel atau protoplasma yang bersifat irreversible (tidak dapat kembali ke asal). Pertumbuhan dan perkembangan terjadi pada makhluk hidup, baik pada manusia, hewan, maupun tumbuhan. Salah satu faktor yang memengaruhi pertumbuhan tanaman adalah faktor lingkungan dimana salahsatunya adalah tanah. Pertumbuhan dan perkembangan tumbuhan membutuhkan nutrisi. Nutrisi ini harus tersedia dalam jumlah cukup dan seimbang, antara satu dengan yang lain. Nutrisi diambil tumbuhan dari dalam tanah dan udara. Unsur-unsur yang dibutuhkan oleh tumbuhan dikelompokkan menjadi dua, yaitu zat-zat organik $(\mathrm{C}, \mathrm{H}, \mathrm{O}$, dan $\mathrm{N})$ dan garam anorganik 
$\left(\mathrm{Fe}^{2+} . \mathrm{Ca}^{2+}\right.$, dan lain-lain). Berdasarkan jumlah kebutuhan tumbuhan, unsur-unsur dapat dikelompokkan menjadi dua, yaitu unsur makro dan unsur mikro. Unsur yang dibutuhkan tumbuhan dalam jumlah besar disebut unsur makro. Contohnya: $\mathrm{C}, \mathrm{H}, \mathrm{O}, \mathrm{N}, \mathrm{P}, \mathrm{K}, \mathrm{S}$, dan asam nukleat. Sedangkan, unsur mikro adalah unsurunsur yang dibutuhkan dalam jumlah sedikit (Rachmawati, 2009).

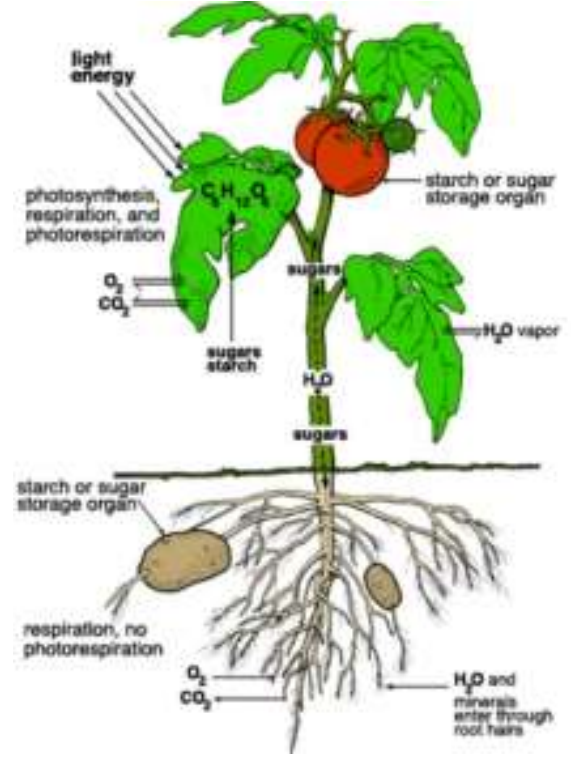

Gambar 3: Bagan Tumbuhan

(Sumber:http://nenarosalia.blogspot.com/2015/ 12/cara-tumbuhan-memperoleh-energi.html)

Kita tahu bahwa tumbuhan memiliki beberapa bagian yang menjadikan stabilnya sistem pada tumbuhan tersebut. Daun, batang, bunga, dan akar meupakan komponen utama pada tumbuhan. Bagian tumbuhan yang berada di tanah adalah akar. Akar sangat berpengaruh karena Akar memiliki fungsi untuk menambatkan tubuh tumbuhan pada tanah atau medium tumbuhnya, menyerap air dan mineral dalam tanah atau pada medium tumbuhnya.

Akar merupakan organ tumbuhan yang umumnya berada di bawah permukaan tanah, tidak memiliki buku-buku, tumbuh ke pusat bumi atau menuju air, warna tidak hijau (keputih-putihan atau kekuning-kuningan), dan memiliki bentuk meruncing. Terdapat dua jenis sistem perakaran pada tumbuhan, yaitu serabut dan tunggang. Tumbuhan monokotil seperti padi, jagung, dan rumput memiliki sistem perakaran serabut. Sebaliknya pada tumbuhan dikotil seperti kacang tanah dan mangga memiliki sistem perakaran tunggang (Rachmawati, 2009).

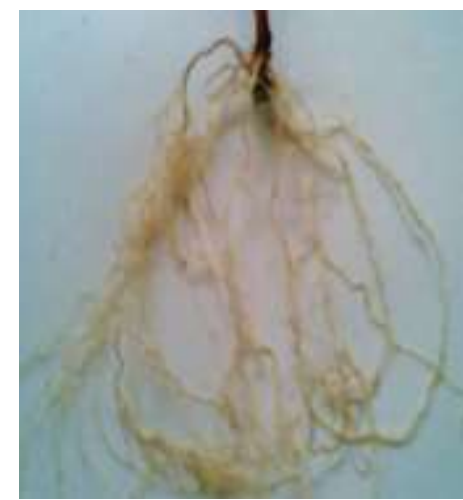

Gambar 4: Akar serabut

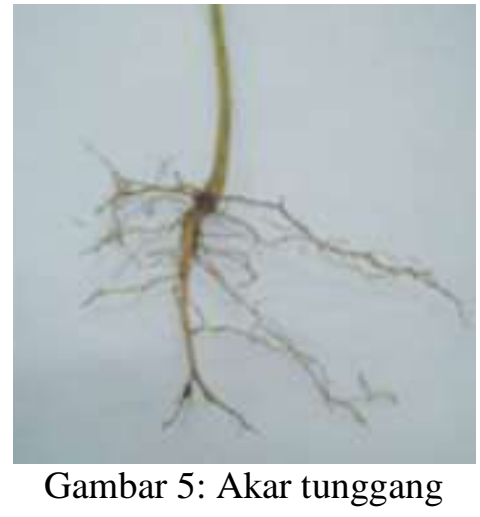

Jenis akar tidaklah memengaruhi dalam pertumbuhan tanaman. Karena pada dasarnya tanaman akan tumbuh dengan baik jika terdapat tanah (media) yang subur. Unsur hara berperan penting dalam pertumbuhan tanaman. Jika unsur hara sedikit maka dapat dikatakan tanah tersebut kurang subur atau tidak subur. Sedangan jika unsur hara dalam tanah tersebut lengkap atau banyak maka tanah itu termasuk tanah yang subur. Tanah yang subur memberikan nutrisi bagi tanaman dengan penyerapan melalui akar. Sebagai contoh yaitu tanaman bayam berikut:

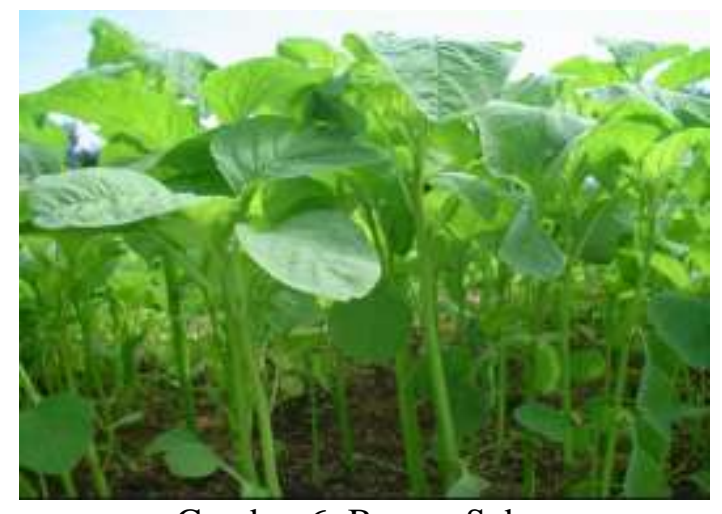

Gambar 6: Bayam Subur

(Sumber:http://carakumenanam.com/bayam/) 


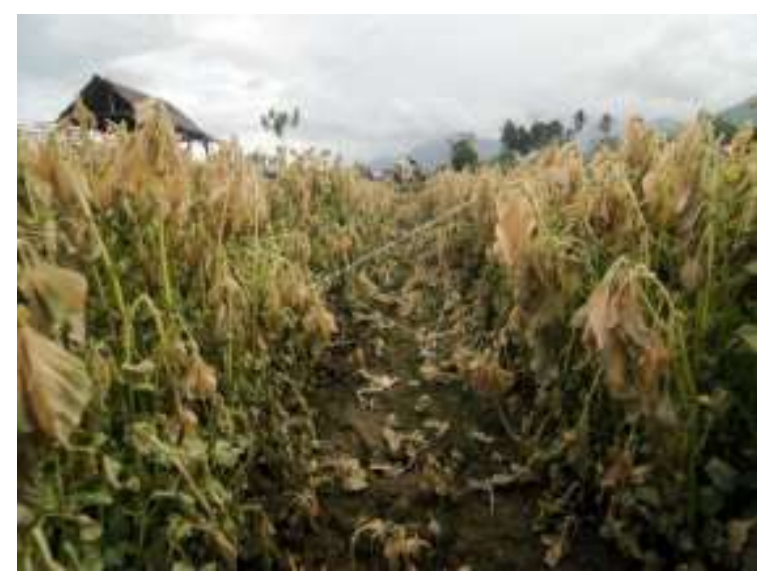

Gambar 7 : Bayam Layu.

(Sumber:https://www.antarafoto.com/bisnis/v1 389009601/sayur-bayam-dibiarkan-mati)

Tanaman bayam diatas merupakan contoh dari tanah yang subur berpengaruh terhadap pertumbuhan tanaman. Kandungan unsur hara yang baik bagi bayam mampu memenuhi nutrisi yang dibutuhkan oleh bayam (akar serabut). Tanaman yang tumbuh subur mendapatkan nutrisi berupa mineral dari tanah (media). Sementara tanaman yang tidak tumbuh dengan baik dapat kita prediksi bahwa kandungan tanah yang tidak subur memengaruhinya. Dapat kita dilihat bahwa tanaman yang tumbuh subur terlihat segar. Dan tanaman yang layu tidak dapat tumbuh lebih lama dan hanya menjadi jasad tumbuhan.

\section{d. Deskripsi Saintifik QS. Al A'raf Ayat 58}

Deskripsi menurut Kamus Besar

Bahasa Indonesia adalah pemaparan atau penggambaran dengan kata-kata secara jelas dan terperinci (Setiawam, 2010). Sehigga hal-hal yang bersifat masih global akan dikupas lebih detail dan lengkap. Sedangkan Sains adalah pengetahuan sistematis yg diperoleh dr sesuatu observasi, penelitian, dan uji coba yg mengarah pd penentuan sifat dasar atau prinsip sesuatu yg sedang diselidiki, dipelajari, dsb (Setiawan, 2010). Dengan menggunakan integrasi, berati kita akan mengetahui secara utuh keterkaitan antara ilmu sains dan ilmu agama yang berbeda.

Dalam Jurnal Al-Qur'an dan Lahirnya Sains Teistik, dijelaskan bahwa agama dan sains atau tentang gagasan pengembangan sains yang berbasis agama, sudah sampai pada upaya membangunnya berdasarkan bangunan keilmuan (scientific building) dalam bentuk paradigma ilmiah (scientific paradigm). Wacana ikut memperkaya kajian di bidang studi al-
Qur'an. Sebagai sumber pokok agama Islam, alQur'an tidak hanya menjadi perhatian kajian studi al-Qur'an dan tafsir, tetapi juga menjadi perhatian kajian Filsafat Ilmu terutama dalam kaitannya dengan pola pengembangan sains berbasis agama (Muslih, 2016). Mengingat ilmu sains yang selalu dinamis, deskripsi Al-Qur'an sangat tepat untuk mengupasnya lebih lanjut disiplin ilmu sains.

Adapun arah dan tujuan ilmu pengetahuan bahwa ayat Al-Qur'an begitu banyak yang berbicara tujuan ilmu seperti untuk mengenal tanda-tanda kekuasaan-Nya, menyaksikan kehadirna-Nya diberbagai fenomena yang kita amati mengagungkan Allah serta bersyukur kepada-Nya. Disamping itu, AlQur'an menyebutkan pula tiga hal lainnya dalam mengembangkan ilmu antara lain

1. Ilmu pengetahuan harus menemukan keteraturan (sistem), hubungan sebab akibat dan tujuan di alam semesta.

2. Ilmu harus dikembangkan untuk mengambil manfaat dalam rangka mengabdi kepada Allah, sebab Allah Swt. telah menundukkan segala apa yang ada di langit dan di bumi untuk kepentingan manusia.

3. Ilmu harus dikembangkan dengan tidak menimbulkan kerusakan di bumi. (Hasim, 2013)

Dalam QS. Al Araf Ayat 58 yang berbunyi

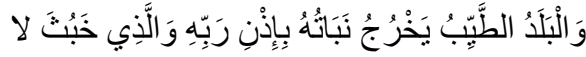

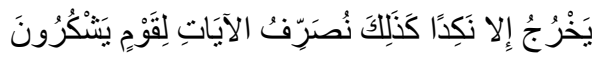
tanamannya tumbuh subur dengan izin Tuhan dengan pemeliharanya; dan (tanah) yang buruk, tanaman-tanamannya tumbuh merana. Demikianlah Kami menjelaskan berulang-ulang tanda-tanda (kebesaran Kami) bagi orang-orang yang bersyukur."

Maksud "tanah yang baik" di ayat tersebut adalah tanah yang subur. Dimana tanah tersebut secara sains terdapat berbagai komponen yang terkandung dalam tanah tersebut. Tanah yang baik akan berfungsi sebagai media tanaman untuk tumbuh. Sebagai contoh sebelumnya adalah tanaman bayam yang tumbuh dengan baik (segar) karena media (tanah) yang ditempatinya juga baik (subur). Hal tersebut tentu dengan izin Allah Swt. yang mengatur seluruh alam ini. Karena ada juga tanaman yang justru tidak dapat tumbuh di tanah yang memeiliki banyak unsur hara karena beberapa faktor. 
Sementara tanaman yang tumbuh subur dengan izin Allah sudah dapat kita ketahui adalah tanaman yang memiliki berbagai bagian yang berfungsi secara baik seperti akar untuk menyerap air dan mineral dalam tanah yang subur. Sesuai dengan yang ada di QS. Al-A'raf ayat 58, tanaman akan tumbuh subur jika tanahnya baik yaitu memiliki unsur yang mendukung pertumbuhan tanaman. Unsur hara yang terdapat dalam tanah salah satunya berasal dari hujan yang diturunkan dari langit. Air hujan akan menjaga kelembapan tanah dan membuat tanah menjadi baik untuk pertumbuhan tanaman.

Dari sini jelas ada hubungan antara ilmu sains dan ilmu agama. Dari sisi agama (AlQur'an) yang sudah pasti kebenarannya, ayat tersebut tentu bagi orang awam masih berpikir secara global bahwa tanah memiliki pengaruh dalam pertumbuhan tanaman. Adanya ilmu sains akan menjelaskan kita detail keilmuan dari dua sisi yang berbeda. Sains menjelaskan secara detail tentang tanah yang subur. Salah satu cara untuk mendapatkan tanah yang subur adalah dengan cara menjaga lingkungan yang ada. Dengan memelihara lingkungan, disana pula akan ada tanah yang baik (subur) dan tanaman yang mampu tumbuh dengan baik. Hal itu merupakan salah satu cara bagi kita mensyukuri atas apa yang Allah berikan. Sesuai dengan salah satu cabang ilmu sains fisika lingkungan yang menyerukan kepada kita untuk bisa menjaga lingkungan dimana kita tinggal. Karena itu adalah salah satu tugas dari kita sebagai khalifah (pemimpin) di muka bumi ini. Bisa jadi tanah yang subur itu merupakan sumber rezeki yang halal untuk dimanfaatkan melihat kebutuhan manusia yang selalu bergantung pada alam.

\section{Simpulan}

Melalui kajian deskripsi antara pernyataan yang ada di Al-Qur'an dan ilmu sains, kita dapat mengetahui terdapat isyarat ilmiah. Tanah dan tanaman diciptakan oleh Allah agar dapat bermanfaat bagi manusia. Tanah yang subur memiliki berbagai unsur hara yang diperlukan tanaman seperti unsur $\mathrm{N}$. Kesuburan tanah merupakan faktor utama ada pertumbuuhan tanaman. Hal ini karena tanah berfungsi sebagai media tanam.

Ada banyak cara manusia untuk menjaga kesuburan tanah diantaranya ikut serta dalam konservasi lingkungan. Menjaga tanah yang subur merupakan upaya manusia mengamalkan QS. Al A'raf ayat 58. Sains dan Agama memiliki hubungan erat yang saling melengkapi satu sama lain. Dengan belajar integrasi, kita akan mengetahui hubungan antara sains dan agama secara lebih detail. Maka dari itu, integrasi QS. Al A'raf ayat 58 yang dapat dijelaskan dengan pengaruh tanah terhadap pertumbuhan tanaman. Allah akan menjadikan tanaman itu tumbuh subur apabila berada di tanah yang baik dan itu sudah terbukti dengan ilmu sains. Sebagai umat islam, kita dapat belajar keilmuan dari sisi agama dan sisi ilmu umum yang diharapkan mampu meningkatkan keimanan kita.

Dengan begitu, manusia diharapkan selalu bersyukur terhadap apa yang diberikan oleh Allah yang kemudian dapat dimanfaatkan sebagai lahan tanaman. Manusia yang mampu mengelola tanah dengan baik dapat memanfaatkannya untuk dijadikan sebagai lahan rezeki.

\section{Referensi}

Ali, Hanafiah Kemas. (2005). Dasar-Dasar Ilmu Tanah. Jakarta: PT RajaGrafindo Persada.

Batubara, Hamdan Husein. (2016). Metode dan Model Integrasi Sains dan Islam di Perguruan Tinggi Agama Islam. https://www.researchgate.net/ publication/324744404 _Metode_dan_Model_Integrasi_Sains_ dan_Islam_di_

Perguruan_Tinggi_Agama__ Islam. Diakses tanggal 15 Oktober 2018.

Choiri, Amrul dan Setiaji, Bambang. (2014). AlQur'an dan As-Sunnah Sebagai Sumber Ajaran Islam. Jurnal SUHUF, Vol. 26, No. 2, Nopember 2014: 89-110.

Departemen Agama RI. (2009). Al-Qur'an dan Tafsirnya. Jakarta: Lembaga Percetakan Al-Qur'an Departemen Agama.

Dwi, Anggoro. (2016). Langkah dalam Mengembalikan Kesuburan Tanah. https://kabartani.com/langkah-dalammengembalikan-kesuburan-tanah.html. Diakses tanggal 18 Oktober 2018.

Harahap, Nursapia. (2014). Penelitian Kepustakaan. Jurnal Iqra' Volume 08 No.01. 
Hasyim, Baso. (2013). Islam Dan Ilmu Pengetahuan (Pengaruh Temuan Sains Terhadap Perubahan Islam). Jurnal Dakwah Tabligh, Vol. 14, No. 1, Juni 2013 : 127 - 139

Horiq. (2014). Pendidikan Sains. http://horiq.blog.uns.ac.id/pendidikansains.html. Diakses tanggal 18 Oktober 2018.

Kemendikbud. (2017). Ilmu Pengetahuan Alam SMP Kelas VIII. Jakarta: Kemendikbud.

Muslih, Mohammad. (2016). Al-Qur'an dan Lahirnya Sains Teistik. Jurnal Peradaban Islam Vol. 12, No. 2, November 2016, 257-280

Purwanto, Agus. (2008). Ayat-Ayat Semesta Sisi-Sisi Al-Qur'an yang Terlupakan. Bandung: Mizan Media Utama.

Rachmawati, dkk. (2009). Biologi Untuk SMA/MA Kelas XII. Jakarta: Pusat Perbukuan.
Rifai, Mien. A. (2003). Kamus Biologi. Jakarta: Balai Pustaka.

Rosalia, Nena. (2015). Cara Tumbuhan Memperoleh Energi. http://nenarosalia.blogspot.com /2015/12/cara-tumbuhan-memperolehenergi.html

Setiawan, Ebta. (2010). Kamus Besar Bahasa Indonesia. Jakarta: Pusat Bahasa.

Shihab, M. Quraish. (2013). Al-Qur'an dan Maknanya. Tangerang: Lentera Hati.

Subekti, Wisnu. (2012). Manfaat Belajar Sains. https://www.zenius.net/blog/139/manfa at-belajar-sains. Diakses tanggal 8 Oktober 2018.

https://www.antarafoto.com/bisnis/v138900960 1/sayur-bayam-dibiarkan-mati. Diakses tanggal 18 Oktober 2018.

http://carakumenanam.com/bayam/. Diakses tanggal 18 Oktober 2018, 